\title{
GARIS-GARIS BESAR PENGADAAN BARANG DAN JASA PEMERINTAH
}

\author{
(The Outlines Of Procurement Of Goods And Services Of Government) \\ YUSRI \\ Balai Besar Pelaksanaan Jalan Nasional XI \\ Direktorat Jenderal Bina Marga Kementerian Pekerjaan Umum dan Perumahan Rakyat
}

\begin{abstract}
Procurement of Goods/Services is an activity to obtain goods/services by Ministries/ Institutions/Work Unit of Regional Devices/Institutions which is its process starts from the planning of needs until completion of all activities to obtain goods/services. The procurement of government in goods and services is actually a very important part of the development process. For the government, the availability of goods and services in every government agency will be the determining factor of successful implementation of tasks and functions of each work unit. The procurement of goods and services is not only important for the government, but also important for the community because there are goods and services directly enjoyed by the general public such as roads, bridges, school buildings, hospitals, teacher services, doctors services, lawyers services etc.. The effectiveness of procurement of goods and services is achieved by providing goods and services that are truly useful as needed. To realize the effectiveness of procurement of goods and services then the determination of priority needs into the main consideration. Procurement of goods and services at work units / government agencies should be well planned so as to provide goods / services that can provide the maximum impact on the performance of government agencies in carrying out its duties and functions
\end{abstract}

Keywords: Procurement of government in goods and services

\section{ABSTRAK}

Pengadaan Barang/Jasa adalah kegiatan untuk memperoleh Barang /Jasa oleh Kementerian/Lembaga/Satuan Kerja Perangkat Daerah /Institusi yang prosesnya dimulai dari perencanaan kebutuhan sampai diselesaikannya seluruh kegiatan untuk memperoleh Barang/Jasa. Pengadaan barang dan jasa pemerintah sesungguhnya merupakan bagian yang sangat penting dalam proses pelaksanaan pembangunan. Bagi pemerintah, ketersediaan barang dan jasa pada setiap instansi pemerintah akan menjadi faktor penentu keberhasilan pelaksanaan tugas dan fungsi masing-masing unit kerja. Pengadaan barang dan jasa tidak hanya penting bagi jajaran pemerintah, tetapi juga penting bagi masyarakat karena di dalamnya terdapat barang dan jasa yang langsung dinikmati oleh masyarakat umum seperti jalan, jembatan, gedung sekolah, rumah sakit, jasa guru, jasa dokter, jasa pengacara dan sebagainya. Efektifitas pengadaan barang dan jasa dicapai dengan cara mengadakan barang dan jasa yang benar-benar bermanfaat sesuai dengan kebutuhan. Untuk mewujudkan efektifitas pengadaan barang dan jasa maka penentuan prioritas kebutuhan menjadi pertimbangan utama. Pengadaan barang dan jasa pada satuan kerja/instansi pemerintah harus direncanakan dengan baik sehingga mampu menyediakan barang/jasa yang dapat memberikan dampak maksimal terhadap kinerja instansi pemerintah dalam melaksanakan tugas dan fungsinya

Kata Kunci: Pengadaan barang dan jasa pemerintah 


\section{PENDAHULUAN}

Pengadaan barang dan jasa pemerintah sesungguhnya merupakan bagian yang sangat penting dalam proses pelaksanaan pembangunan. Bagi pemerintah, ketersediaan barang dan jasa pada setiap instansi pemerintah akan menjadi faktor penentu keberhasilan pelaksanaan tugas dan fungsi masing-masing unit kerja. Pengadaan barang dan jasa tidak hanya penting bagi jajaran pemerintah, tetapi juga penting bagi masyarakat karena di dalamnya terdapat barang dan jasa yang langsung dinikmati oleh masyarakat umum seperti jalan, jembatan, gedung sekolah, rumah sakit, jasa guru, jasa dokter, jasa pengacara dan sebagainya. Efektifitas pengadaan barang dan jasa dicapai dengan cara mengadakan barang dan jasa yang benar-benar bermanfaat sesuai dengan kebutuhan.

Efektifitas pengadaan barang dan jasa dicapai dengan cara mengadakan barang dan jasa yang benar-benar bermanfaat sesuai dengan kebutuhan. Untuk mewujudkan efektifitas pengadaan barang dan jasa maka penentuan prioritas kebutuhan menjadi pertimbangan utama.

\section{TUJUAN}

Untuk mewujudkan efektifitas pengadaan barang/jasa maka penentuan prioritas kebutuhan menjadi pertimbangan utama.

\section{MANFAAT}

Untuk mewujudkan efektifitas pengadaan barang dan jasa maka penentuan prioritas kebutuhan menjadi pertimbangan utama. Pengadaan barang dan jasa pada satuan kerja/instansi pemerintah harus direncanakan dengan baik sehingga mampu menyediakan barang/jasa yang dapat memberikan dampak maksimal terhadap kinerja instansi pemerintah dalam melaksanakan tugas dan fungsinya.

\section{KAJIAN PUSTAKA}

Pengadaan Barang dan Jasa

\section{Pengadaan Barang dan Jasa Bagi Instistusi Pemerintah}

Definisi tentang pengadaan barang/jasa pemerintah terdapat dalam pasal 1 angka 1 Peraturan Presiden nomor 4 tahun 2015 yang berbunti: "Lembaga Kebijakan Pengadaan Barang/Jasa Pemerintah yang selanjutnya disebut LKPP adalah lembaga Pemerintah yang bertugas mengembangkan dan merumuskan kebijakan Pengadaan Barang/Jasa sebagaimana dimaksud dalam Peraturan Presiden Nomor 106 Tahun 2007 tentang Lembaga Kebijakan Pengadaan Barang/Jasa Pemerintah sebagaimana diubah dengan Peraturan Presiden Nomor 157 Tahun 2014 tentang Perubahan atas Peraturan Presiden Nomor 106 tahun 2007 tentang Lembaga Kebijakan Pengadaan Barang/Jasa Pemerintah".

Pengadaan barang dan jasa pemerintah sesungguhnya merupakan bagian yang sangat penting dalam proses pelaksanaan pembangunan. Bagi pemerintah, ketersediaan barang dan jasa pada setiap instansi pemerintah akan menjadi faktor penentu keberhasilan pelaksanaan tugas dan fungsi masing-masing unit kerja. Tanpa sarana dan prasarana yang memadai tentu saja jalannya pelaksanaan tugas pemerintah akan terganggu dan tidak akan mencapai hasil yang maksimal.

Efisiensi dalam pengadaan barang dan jasa dicapai dengan cara menggunakan dana anggaran yang terbatas untuk memperoleh barang dan jasa dalam jumlah maksimal, atau 
untuk memperoleh seluruh barang dan jasa yang sudah ditetapkan sebagai sasaran yang hendak dicapai atau kegiatan yang hendak dilaksanakan menggunakan dana anggaran seminimal mungkin.

\section{Penggolongan Barang dan Jasa}

Jenis barang dan jasa yang dibutuhkan oleh instansi pemerintah digolongkan dalam 4 macam barang/jasa yaitu:

1. Barang adalah setiap benda baik maupun tidak berwujud, bergerak maupun tidak bergerak, yang dapat diperdagangkan, dipakai, dipergunakan atau dimanfaatkan oleh pengguna barang.

2. Pekerjaan Kontruksi adalah seluruh pekerjaan yang berhubungan dengan pelaksanaan kontruksi bangunan atau pembuatan wujud fisik lainnya.

3. Jasa Konsultasi adalah jasa layanan profesional yang membutuhkan keahlian tertentu di berbagai bidang keilmuan yang mengutamakan adannya olah pikir (brainware).

4. Jasa lainnya adalah jasa yang membutuhkan kemampuan tertentu yang mengutamakan keterampilan (skillware) dalam satu sistem tata kelola yang telah dikenal luas di dunia usaha untuk menyelesaikan suatu pekerjaan atau segala pekerjaan dan/atau penyediaan jasa selain jasa Konsultasi, Pelaksanaan Pekerjaan Konstruksi dan Pengadaan Barang.

Pengadaan barang/jasa pemerintah dapat dilakukan dengan dua cara yaitu: pengadaan barang/jasa dengan cara swakelola dan pengadaan barang/jasa melalui penyedia.

1. Pengadaan barang/jasa dengan cara swakelola sebagaimana diatur dalam pasal
26 Perpres nomor 54 tahun 2010 adalah merupakan kegiatan pengadaan barang/jasa dimana pekerjaannya direncanakan, dikerjakan dan /atau diawasi sendiri oleh Kementerian/Lembaga/Pemerintah

Daerah/Institusi (K/L/D/l) sebagai penanggung jawab anggran, instansi pemerintah lain dan/atau kelompok masyarakat.

2. Pengadaan barang/jasa melalui penyedia adalah pengadaan barang/jasa yang dilaksanakan oleh penyedia barang/jasa. Penyedia barang/jasa adalah badan usaha atau orang perseorangan yang menyediakan barang/pekerjaan kontruksi/jasa konsultasi/jasa lainnya.

\section{Unit Layanan Pengadaan (ULP)}

Dalam pasal 14 Perpres nomor 70 tahun 2012 telah dietapkan bahwa setiap Kementerian/Lembaga/Pemerintah

Daerah/Institusi (K/L/D/I) paling lambat tahun anggaran 2014 harus mempunyai Unit Layanan Pengadaan (ULP) yang daoat memberikan pelayanan dan pembinaan di bidang pengadaan barang/jasa. Unit ini merupakan suatu unit kerja yang berfungsi memberikan pelayanan di bidang pengadaan barang/jasa pada K/L/D/I bersangkutan.

Menurut pasal 7 ayat 4 Perpres 70 tahun 2012 perangkat organisasi ULP ditetapkan sesuai dengan Peraturan Perundang-undangan. Peraturan Perundang-undangan yang dimaksud adalah perundang-undangan di bidang kelembagaan dan pendayagunaan aparatur negara. Sampai dengan saat ini peraturan di bidang kepegawaian tersebut terutama yang menyangkut struktur organisasi edan peraturan 
tentang tunjangan dan penggajian bagi pegawai unit ULP belum ada. Karena itu sementara peraturan perundang-undangan dimaksud belum ada, maka perangkat organisasi ULP masih mengacu pada Perpres nomor 54 tahun 2010 yaitu terdiri dari:

1. Kepala;

2. Sekretariat;

3. Staf Pendukung;

4. Kelompok Kerja.

\section{Kelompok Kerka ULP}

Unit layanan pengadaan merupakan suatu organisasi atau satuan kerja yang bersifat permanen dalam suatu Kementerian/Lembaga/Daerah/Institusi yang berfungsi melaksanakan pengadaan barang/jasa. Menurut pasal 15 ayat 1 Perpres nomor 70 tahun 2012 pemilihan penyedia barang/jasa dalam ULP dilakukan oleh kelompok kerja ULP. Pemilihan penyedia nbarang/pekerja kontruksi/jasa lainnya yang bernilai di atas $\mathrm{Rp} 200.000 .000$,- (dua ratus juta rupiah) dan pemilihan penyedia jasa konsultasi yang bernilai di atas Rp. 50.000.000,9lima puluh juta rupiah) dilaksanakan oleh Kelompok Kerja ULP. Anggota kelompok kerja ULP berjumlah gasal beranggotakan paling kurang 3 (tiga) orang dan dapat ditambah sesuai dengan kompleksitas pekerjaan.

\section{Aparat Pelaksana Pengadaan Barang/Jasa}

Aparat pelaksana pengadaan brang/jasa pemerintah yang terdiri dari:

1. Pengguna Anggaran/Kuasa Pengguna
Anggran

2. Pejabat Pembuat Komitmen (PPK)

3. Pejabat Pengadaan

4. Panitia /Pejabat Penerima Hasil Pekerjaan

5. Pejabat Pelaksana Teknis Kegiatan (PPTK)

\section{Prinsip dan Kebijakan dalam Pengadaan Barang/Jasa}

Menurut pasal 5 Peraturan Presiden nomor 54 tahun 2010 pengadaan barang dan jasa pemerintah (PBJ) dilaksanakan berdasarkan pada prinsip dasar sebagai berikut:

a. Efisien

b. Efektif;

c. Transparan;

d. Terbuka;

e. Bersaing;

f. Adil/tidak diskriminatif; dan

g. Akuntabel.

\section{Etika dalam Pengadaan Barang/Jasa}

Etika dalam pengadaan barang dan jasa pemerintah te;ah dituagkan dalam pasal Perpres nomor 54 tahun 2010 yang berbunyi:

1. Melaksanakan tugas secara tertib, disertai rasa tanggung jawab untuk mencapai sasaran kelancaran dan ketetapan tercsapainya tujuan pengadaan barang/jasa;

2. Bekerja secara profesional dan mandiri atas dasar kejujuran, serta menjaga kerahasiaan dokumen pengadaan barang dan jasa yang seharusnya dirahasikan untuk mencegah terjadinya penyimpangan dalam pengadaan barang/jasa;

3. Tidak saling mempengaruhi baik langsung maupun tidak langsung yang berakibat terjadinya persaingan yang tidak sehat;

4. Menerima dan bertanggung jawab atas segala keputusan yang ditetapkan sesuai dengan kesepakatan para pihak;

5. Menghindari dan mencegah terjadinya pertentangan kepentingan (conflict of interest) diantara para pihak yang terkait baik langsung 
maupun tidak langsung dalam proses pengadaan barang/jasa;

6. Menghindari dan mencegah terjadinya pemborosan dan kebocoran keuangan negara dalam pengadaan barang/jasa;

7. Menghindari dan mencegah penyalahgunaan wewenang dan/atau kolusi dengan tujuan untuk keuntungan pribadi, golongan atau pihak lain yang secara langsung atau tidak langsung merugikan negara; Tidak menerima, tidak menawarkan atau tidak menjanjikan untuk memberikan atau menerima hadiah, imbalan, komisi, rabat dan berupa apa saja dari atau kepada siapapun yang diketahui atau patut dapat diduga berkaitan dengan pengadaan barang/jasa.

\section{Kebijakan dalam Pengadaan Barang/Jasa}

Kebijakan hanya boleh diambil oleh pejabat yang berwenang sesuai dengan kewenangannya. Karena kebijakan harus dituangkan dalam peraturan perundang-undangan maka kewenangan untuk menentukan suatu kebijakan pemerintah berada pada pejabat yang berwenang untuk membuat perundang-undangan. Setiap perubahan terhadap kebijakan yang telah diatur dalam suatu perundang-undangan harus dilakukan dengan merubah peraturan yang telah ada lebih dahulu. Kebijakan pemerintah tentang tersebut dituangkan dalam Peraturan Presiden nomor 54 tahun 2010 dan nomor 70 tahun 2012 adalah sebagai berikut:

1. Peningkatan penggunaan produksi Barang/Jasa dalam negeri

2. Keamndirian industri pertahanan, industri Alat Utama Sistem Senjata (Alutsista), industri Alat Material Khusus (Almatsus) dalam negeri.
3. Peningkatan peran serta Usaha Mikro, Usaha Kecil, Koperasi kecil, dan kelompok masyarakat.

4. Perhatian terhadap aspek pemanfaatan sumber daya alam dan pelestarian fungsi lingkungan hidup.

5. Peningkatan penggunaan teknologi informasi dan transaksi elektronik.

6. Penyederhanaan ketentuan dan tata cara untuk mempercepat proses pengambilan keputusan.

7. Peningkatan profesionalismes, kemandirian, dan tanggung jawab para pihak.

8. Peningkatan penerimaan negara melalui sektor perpajakan.

9. Menumbuhkembangkan peran usaha nasional.

10. Menumbuhkankembangkan industri kreatif inovatif, budaya dan hasil penelitian laboratorium atau industri pendidikan dalam negeri.

11. Memanfaatkan sarana/prsarana penelitian dan pengembangan dalam negeri

12. Pelaksanaan pengadaan barang/jasa di dalam wilayah Negara Kesatuan Republik Indonesia, termasuk di Kantor nPerwakilan Republik Indonesia; dan Mengumumkan secara terbuka rencana dan pelaksanaan Pengadaan Barang/Jasa.

\section{Penyedia Barang dan Jasa}

\section{Penyedia Barang dan Jasa Nasional}

Penyedia Barang/Jasa adalah badan usaha atau perseorangan yang pekerjaannya menyediakan barang dan/atau jasa. Penyedia barang/jasa berbentuk badan usaha harus memenuhi persyaratan sebagaimana diatur dalam 
pasal 19 Perpres nomor 70 tahun 2012 berbunyi sebagai berikut:

Penyedia Barang/Jasa dalam pelaksanaan Pengadaan Barang/Jasa wajib memenuhi persyaratan sebagai berikut:

a. Memenuhi ketentuan peraturan perundangundangan untuk menjalankan kegiatan/usaha; pengalaman, kemampuan teknis dan manajerial untuk menyediakan Barang/Jasa;

b. Memperoleh paling kurang 1 (satu) pekerjaan sebagai Penyedia Barang/Jasa dalam kurun waktu 4 (empat) tahun terakhir, baik dilingkungan pemerintah maupun swasta, termasuk pengalaman subkontrak;

c. Ketentuan sebagaimana dimaksud pada huruf c, dikecualikan bagi Penyedia Barang/Jasa yang baru berdiri kurang fari 3 (tiga) tahun;

d. Memiliki sumber daya manusia, modal, peralatan dan fasilitas lain yang diperlukan dalam Pengadaan Barang/Jasa;

e. Dalam hal Penyedia Barang/Jasa akan melakukan kemitraan, Penyedia Barang/Jasa harus mempunyai perjanjian kerjasama operasi/entase kemitraan dan perusahaan yang mewakili kemitraan tersebut;

f. Memiliki kemampuan pada bidang pekerjaan yang sesuai untuk Usaha Mikro, Usaha Kecil, dan koperasi kecil serta kemampuan pada sub bidang pekerjaan yang sesuai untuk usaha non-kecil.

g. Memiliki Kemampuan Dasar (KD) untuk usaha non-kecil, kecuali untuk Pengadaan Barang dan Jasa Konsultansi;

h. Khusus untuk pelelangan dan pemilihan langsung Pengadaan Pekerjaan Konstruksi memiliki dukungan keuangan dari bank; i. Khusus untuk Pengadaan Pekerjaan Kontruksi dan jasa lainnya, harus memperhitungkan Sisa Kemampuan Paket (SKP) sebagai berikut;

$S K P=K P-P$

$\mathrm{KP}=$ nilai kemampuan paket, dengan ketentuan:

a) Untuk Usaha Kecil, nilai Kemampuan Paket (KP) ditentukan sebanyak 5 (lima) paket pekerjaan; dan

b) Untuk usaha non kecil, nilai Kemampuan Paket (KP) ditentukan sebanyak 6 (enam) atau 1,2 (satu koma dua) N.

$\mathrm{P}=$ jumlah paket yang sedang dikerjakan

$\mathrm{N}=$ jumlah paket pekerjaan terbanyak yang dapat ditangani pada saat bersamaan selama kurun waktu (lima) tahun terakhir.

j. Tidak dalam pengawasan pengadilan, tidak palit, kegiatan usahanya tidak sedang dihentikan dan/atau direksi yang bertindak untuj dan atas nama perusahaan tidak sedang dalam menjalani sanksi pidana, yang dibuktikan dengan surat pernyataan yang ditandatangani Penyedia Barang/Jasa;

k. Sebagai wajib pajak sudah memiliki Nomor Pokok Wajib Pajak (NPWP) dan telah memenuhi kewajiban perpajakan tahun terakhir (PPTK Tahunan) serta memiliki laporan bulanan PPh Pasal 21, PPh Pasal 23 (bila ada transaksi), PPh Pasal 25/Pasal 29 dan PPN (bagi Pengusaha Kena Pajak) paling kurang 3 (tiga) bulan terakhir dalam tahun berjalan;

I. Secara hukum mempunyai kapasitas untuk mengikatkan diri pada Kontrak;

m. Tidak masuk dalam daftar hitam

n. Memiliki alamat tetap dan jelas serta dapat dijangkau dengan jasa pengiriman; dan 


\section{o. Menandatangani Fakta Integritas}

\section{Penyedia Barang dan Jasa Asing}

Keikutsertaan penyedia barang/jasa asing dalam pemilihan penyedia barang/jasa di Indonesia hanya dibolehkan dalam hal:

1. Pengadaan pekerjaan kontruksi dengan nilai di atas $\mathrm{Rp}$ 100.000.000.000,- (seratus miliar rupiah)

2. Pengadaan barang/jasa lainnya dengan nilai di atas Rp 20.000.000.000,- (dua puluh miliar rupiah)

3. Pengadaan jasa kontruksi dengaan nilai di atas $\mathrm{Rp}$ 10.000.000.000,- (sepuluh miliar rupiah).

Pasal 19 ayat (1a) Perpres 70 tahun 2012 berbunyi "Dengan tetap mengedepankan prinsipprinsip pengadaan dan kaidah bisnis yang baik, persyaratan bagi Penyedia Barang/Jasa asing dikecualikan dari ketentuan ayat (1) huruf $d$, huruf j, dan huruf I'.

Penjelasan pasal 19 ayat (1a) berbunyi “ yang dimaksud dengan penyedia barang/jasa asing adalah perseorangan warga negara asing atau penyedia barang/jasa yang bukan berbadan hukum Indonesia".

Pasal 19 ayat (1) huruf $d$ mengatur bahwa penyedia barang/jasa yang baru berdiri kurang dari 3 (tiga) tahun yang belum pernah memperoleh pekerjaan dibolehkan menjadi penyedia barang/jasa pemerintah. Peraturan tersebut dibuat sebagai pengeculian bagi penyedia yang baru berdiri kurang dari 3 (tiga) tahun, karena menurut pasal 19 ayat (1) huruf $\mathrm{c}$ Perpres nomor 70 tahun 2012 setiap penyedia barang/jasa harus memperoleh paling kurang 1 (satu) pekerjaan dalam 4 (empat) tahun terakhir.
Dengan adanya pengecualian berdasarkan pasal 19 ayat (1a) maka pengeculian untuk penyedia yang baru berdiri kurang dari 3 (tiga) tahun tidak berlaku bagi penyedia barang/jasa asing. Kalau itu penyedia barang/jasa asing akan penyedia barang/jasa pemerintah Indonesia harus telah pernah mendapat pekerjaan, meskipun badan usaha asing tersebut baru berdiri kurang dari 3 (tiga) tahun.

\section{Penyedia Barang/Jasa Perseorangan}

Berdasarkan ketentuan pada pasal 19 ayat (2) Perpres nomor 70 tahun 2012 tersebut, maka dapat disimpulkan bahwa persyaratan penyedia barang/jasa orang perseorangan sama dengan penyedia barang/jasa berbentuk badan hukum dikurangi keharusan:

1. Pernah memperoleh pekerjaan;

2. Memiliki perjanjian kemitraan;

3. Memiliki Kemampuan Dasar; dan

4. Memiliki dukungan keuangan dari bank.

\section{Dasar-Dasar Pengadaan Barang dan Jasa Metode Pengadaan Barang/Jasa}

Metode atau cara pengadaan barang/jasa pemerintah dapat dilakukan dengan dua cara yaitu dengan cara swakelola dan penyedia barang/jasa. Swakelola merupakan kegiatan Pengadaan Barang/Jasa dimana pekerjaannya direncakan, dikerjakan dan/atau diawasi sendiri oleh $\mathrm{K} / \mathrm{L} / \mathrm{D} / \mathrm{l}$ sebagai penanggung jawab anggaran, instansi pemerintah lain dan/atau kelompok masyarakat.

\section{Metode pemilihan Penyedia Barang/Jasa}

Metode pemilihan penyedia barang/jasa pemerintah adalah bagaimana cara memilih penyedia barang/jasa yangakan ditunjuk sebagai penyedia barang/jasa bagi suatu instansi pemerintah. 
Cara pemilihan penyedia barang/jasa pemerintah diatur dalam pasal 35 Peraturan Presiden nomor 70 tahun 2012, cara pemilihan penyedia dibedakan menurut:

1. Jenis barang/jasa yang akan diadakan meliputi barang/jasa konsultansi/pekerjaan kontruksi/jasa lainnya

2. Jumlah nilai paket

Cara pemilihan penyedia barang/pekerjaan kontruksi/jasa nlainnya yang dapat digunakan menurut Perpres nomor 70 tahun 2012 terdiri dari:

1. Pelelangan umum;

2. Pelelangan terbatas;

3. Pelelangan sederhana;

4. Pemilihan langsung;

5. Penunjukan langsung;

6. Pengadaan langsung;

7. Sayembara; dan

8. Kontes

\section{Penilaian Kualifikasi Penyedia Barang/Jasa}

Persyaratan yang ditetapkan dalam proses lelang harus merupakan persyaratan yang minimal. Contohnya dalam pasal 19 Perpres nomor 70 tahun 2012 ditetapkan bahwa penyedia harus memperoleh paling kurang 1 (satu) pekerjaan dalam kurun waktu 4 (empat) tahun terakhir, baik di lingkungan pemerintah maupun swasta, termasuk pengalaman subkontrak.

Persyaratan kualifikasi penyedia barang/jasa pemerintah telah diatur dalam peraturan perundang-undangan antara lain:

1. Perpres no mor 70 tahun 2012 pasal 19 ayat 1 (satu), mengatur persyaratan penyedia barang/jasa pada umumnya;

2. Suarat Edaran Menteri Pekerjaan Umum nomor 10/SE/M/2012 tanggal 4 Desember
2012, mengatur tentang Sertifikat Badan Usaha (SBU),

3. Sertifikat Keahlian (SKA), dan Sertifikat Keterampilan (SKT) pada Pelaksanaan Pengadaan Pekerjaan Konstruksi dan Jasa Konsultansi serta Kualifikasi Penyedia Jasa Konstruksi;

Peraturan Lembaga pengembangan Jasa Konstruksi Nomor 11 a Tahujn 2012 tentang Registrasi Usaha Jasa Pelaksana Konstruksi.

\section{Penjelasan Dokumen (Aanwijzing)}

Penjelasan dokumen lelang (Aanwijzing) dilakukan sebagai salah satu wujud dari penerapan prinsip transparansi. Penjelasan dokumen pemilihan penyedia barang/jasa bertujuan agar tercapainnya kebersamaan persepsi/pengertian anatar ULP/Pejabat Pengadaan dan calon penyedia barang/jasa terhadap dokumen pemilihan pemilihan penyedia barang/jasa dapat menyusun dan menyampaikan dokumen lelang dengan cara yang benar sesuai dengan apa yang telah dituangkan dalam dokumen pemilihan penyedia barang/jasa.

\section{Metode Penyampaian Dokumen Penawaran}

Metode penyampaian dokumen penawaran dapat dilakukan dengan tiga cara yaitu:

1. Metode satu sampul digunakan untuk pengadaan barang/jasa yang sederhana, dimana evaluasi teknis tidak dipengaruhi oleh harga dan memiliki karakteristik.

2. Metode dua sampul digunakan untuk pengadaan barang/jasa dimana evaluasi teknis dipengaruhi oleh penawaran harga dan untuk pengadaan barang/pekerjaan konstruksi/jasa lainnya yang menggunakan evaluasi sistem nilai atau sistem biaya selama 
umur ekonomis, dan pengadaan jasa konstruksi yang memiliki karakteristik.

3. Metode dua tahap digunakan untuk pengadaan barang/pekerjaan konstruksi /jasa lainnya yang memiliki karakteristik.

\section{Metode Evaluasi Dokumen}

Metode evaluasi dokumen penawaran adalah cara menilai dokumen penawaran dari penyedia barang/jasa dalam rangka menemukan pemenang pemilihan penyedia barang/jasa.

\section{Jaminan dan Garansi}

Surat jaminan adalah jaminan tertulis yang bersifat mudah dicairkan dan tidak bersyarat (unconditional), yang dikeluarkan oleh Bank Umum/Perusahaan Penjaminan/Perusahaan Asuransi yang mempunyai program asuransi kerugian (suretyship) sebagaimana ditetapkan oleh Menteri Keuangan. Jaminan penawaran diserahkan oleh penyedia Barang/Jasa kepada Pejabat Pembuat Komitmen/Unit Layanan Pengadaan untuk menjamin terpenuhnya kewajiban Penyedia Barang/Jasa. Surat jaminan terdiri dari:

1. Surat Jaminan penawaran;

2. Surat Jaminan Pelaksanaan;

3. Surat Jaminan Uang Muka;

4. Surat Jaminan Pemeliharaan;

5. Surat Jaminan Sanggah Banding.

\section{Bukti Pengadaan/Pembelian}

Bukti pengadaan adalah bukti terjadinya transaksi jual beli antara pemerintah dengan penyedia brang/jasa. Yang dimaksud dengan bukti pembelian adalah segala macam bukti tertulis yang menunjukkan telah terjadinya pembelian barang secara dan telah dibayar lunas.

\section{Harga Perkiraan Sendiri (HPS)}

Harga Perkiraan Sendiri (HPS) adalah harga perkiraan yang disusun oleh PPK sebagai dasar untuk melaksanakan pengadaan barang/jasa pemerintah. Penyususnan HPS ditujukan agar dalam pengadaan barang/jasa, harga barang/jasa yang akan dilaksanakan tersebut telah diketahui lebih dahulu sebelum proses pengadaan dilaksanakan.

\section{Pengumuman Lelang}

Pengumuman lelang merupakan awal dari pelaksanaan proses pemilihan penyedia barang/jasa. Dalam hal proses lelang dilakukan dengan cara prakualifikasi pengumuman lelang disebut pengumuman prakualifikasi. Jika lelang dilaksanakan dengan cara pasca kualifikasi pengumuman lelang disebut pengumuman lelang.

\section{Jenis Kontrak}

Peraturan Presiden R.I nomor 70 tahun 2012 tentang revisi kedua Peraturan Presiden nomor 54 tahun 2010 tentang Pengadaan Barang/Jasa Pemerintah pasal 50 menggolongkan jenis kontrak pengadaan barang/jasa pemerintah berdasarkan:

1. Cara pembayaran;

2. Pembebanan tahun anggran;

3. Sumber pendanaan; dan

4. Jenis pekerjaan

\section{Sanggahan}

Salah satu upaya dalam menciptakan proses pemilihan penyedia barang/jasa yang kredible adalah dengan memberikan kesempatan kepada setiap peserta pelelangan untuk mengajukan sanggahan terhadap keputusan Kelompok Kerja ULP berkenaan dengan penetapan hasil prakualifikasi dan pemenang lelang. Sanggahan dapat diajukan oleh peserta 
pemilihan penyedia secara sendiri-sendiri ataupun bersama-sama kepada kelompok Kerja ULP.

\section{Sanggah Banding}

Sangggahan banding harus dijamin dengan surat jaminan sanggah banding yang ditujukan kepada kelompok kerja ULP. Nilai jaminan sanggah banding minimal $1 \%$ (satu perseratus) dari nilai total HPS.

\section{Berita Acara Hasil Pelelangan}

Berita Acara Hasil Pelelangan (BAHP) merupakan kesimpulan dari hasil evaluasi administrasi, teknis dan harga yang dibuat oleh Kelompok Kerja ULP ditandatangani oleh paling kurang $1 / 2$ (seperdua) dari jumlah anggota Kelompok Kerja ULP.

\section{Surat Penunjukkan Penyedia Barang/Jasa}

Surat Penunjukan Penyedia Barang/Jasa (SPPBJ) diterbitkan dan ditandatangani oelh PPK berdasarkan Berita Acara Hasil Pelelangan atau Berita Acara Hasil Seleksi. SPPBJ disampaikan oleh PPK kepada penyedia yang telah ditetapkan sebagai pemenang.

\section{Persiapan Pengadaan Barang dan Jasa}

Rencana Umum Pengadaan (RUP)

1. Penyusunan rencana Umum Pengadaan (RUP)

2. Pengkajiaan Ulang Rencana Pengadaan

3. Pengkajian Ulang Rencana Penganggaran

4. Pengkajian Ulang KAK

5. Pengumuman Rencana Umum

\section{Spesifikasi Teknis Barang}

Pengadaan barang/jasa pada setiap instansi pemerintah harus dilaksanakan berdasarkan prinsip-prinsip pengadaan seperti efektif, efisien, dan adil.

Prinsip efektif menghendaki pengadaan barang/jasa pemerintah harus menghasilkan barang/jasa yang benar-benar dapat meningkatkan kinerja instansi pemerintah. Melalui proses pengadaan PPK harus dapat memperoleh babarang/jasa yang benar-benar sesuai dengan kebutuhan pengguna akhir (end user).

\section{Penetapan Harga Perkiraan Sendiri}

Nilai total HPS yang terlalu rendah dapat menyebabkan kegagalan proses lelang karena tidak ada penyedia yang masukkan penawaran. Sebaliknya nilai HPS yang terlalu tinggi selain dapat membuka kesempatan untuk melakukan mark-up dapat merugikan pihak penyedia barang/jasa sebagai peserta pelelangan.

\section{Draft Kontrak}

Kontrak adalah suatu perikatan anatar para pihak. Dalam pengadaan barang/jasa pemerintah kontrak adalah perikatan antara PPK yang bertindak untuk dan atas nama pemerintah dengan penyedia yang bertindak untuk dan atas nama perusahaan penyedia barang/jasa.

Penggunaan kontrak dalam pengadaan barang/jasa pemerintah bukan hal yang baru. Karena itu, dalam pengadaan barang dan jasa pemerintah tidak sulit untuk menemukan bentuk kontrak pengadaan barang, pengadaan pekerjaan konstruksi, pengadaan jasa konsultansi, dan pengadaan jasa lainnya.

\section{Penyusunan Lelang}

Sebelum melaksanakan proses pemilihan penyedia barang/jasa baik melalui pelelangan maupun seleksi, kelompok kerja ULP harus menyusun jadwal lelang. Hal yang harus dipertimbangkan dalam menyusun jadwal lelang adalah:

1. Kesesuaian jangka waktu dalam jadwal lelang dengan ketentuan yang ada dalam peraturan yang berlaku tentang pengadaan barang/jasa; 
2. Kecukupan waktu untuk pelaksanaan lelang dan waktu penyelesaian pekerjaan;

3. Antisipasi terhadap hambatan yang timbul selama proses lelang seperti kegagalan lelang, sanggahan, dan sanggah banding.

\section{PEMBAHASAN}

Gambaran atau contoh kasus dalam pengadaan barang dan jasa

Dalam suatu proses lelang dari 10 (sepuluh) peserta yang memasukkan penawaran hanya 6 (enam) penyedia yang lulus dalam evaluasi teknis. 4 (empat) penyedia dinyatakan gugur. Berdasarkan hasil koreksi aritmatik diperoleh nilai penawaran harga terkoreksi dari peserta yang telah lulus evaluasi administrasi dan evaluasi teknis sebagai berikut:

\begin{tabular}{ccc}
\hline $\begin{array}{c}\text { No. } \\
\text { Urut }\end{array}$ & $\begin{array}{c}\text { Nama } \\
\text { Penyedia }\end{array}$ & $\begin{array}{c}\text { Nilai } \\
\text { Penawaran } \\
\text { terkoreksi (Rp) }\end{array}$ \\
\hline 1 & CV. AA & 500.000 .000 \\
\hline 2 & CV. EE & 510.000 .000 \\
\hline 3 & CV. II & 515.000 .000 \\
\hline 4 & CV. OO & 520.000 .000 \\
\hline 5 & CV. UU & 525.000 .000 \\
\hline 6 & CV. CC & 550.000 .000 \\
\hline
\end{tabular}

Berdasarkan data diatas, Kelompok kerja ULP melakukan penilaian kualifikasi terhadap peserta diatas secara berurutan mulai peserta dengan penawaran harga terendah sampai diperoleh pemenang, pemenang cadangan $\mathrm{I}$, dan pemenang cadangan II (kalau ada).

Jika CV. AA memenuhi syarat kualifikasi, maka CV. AA ditetapkan sebagai pemenang. Jika CV. EE memenuhi syarat kualifikasi maka CV. EE ditetapkan sebagai pemenang cadangan I. Jika CV. II juga memenuhi syarat maha CV. II ditetapkan sebagai pemenang cadangan II. Selanjutnya terhadap dokumen penawaran CV.
OO, CV. UU, dan CV. CC tidak perlu dilakukan penilain kualifikasi.

Jika CV. AA tidak memenuhi syarat kualifikasi, sedangkan CV. EE dan CV. II memenuhi syarat kualifikasi, maka CV. AA dinyatakan gugur, CV. EE ditetapkan senagai pemenang dan CV. II ditetapkan sebagai pemenang cadangan I. Selanjutnya kelompok kerja ULP memeriksa dokuman penyedia lainnya secara berurutan mulai dari CV. OO, CV. UU, dan CV. CC sampai diperoleh pemenang cadangan II.

Dalam hal dari keenam peserta tersebut diatas hanya ada satu peserta yang memenuhi syarat kualifikasi maka kelompok kerja ULP menetapkan pemenang lelang tanpa pemenang cadangan.

Dalam hal hanya ada dua penyedia yang memenuhi syarat kualifikasi maka kelompok kerja ULP menetapkan pemenang dan pemenang cadangan I.

Dalam hal dari keenam penyedia di atas tidak ada yang memenuhi syarat kualifikasi maka kelompok kerja ULP menyatakan lelang gagal dan melakukan lelang ulang.

Pada dasarnya sesuai dengan prinsip terbuka, pemilihan penyedia barang/jasa harus dilakukan dengan cara prakualifikasi. Meskipun demikian jika kegiatan pengadaan barang/jasa tersebut membutuhkan penyedia dengan kriteria tertentu dapat saja dilakukan dengan cara prakualifikasi. Pemilihan metode kualifikasi yang tepat dalam pengadaan barang/jasa adalah sebagai berikut: 


\begin{tabular}{|c|c|}
\hline $\begin{array}{c}\text { METODE } \\
\text { PRAKUALIFIKASI }\end{array}$ & $\begin{array}{l}\text { METODE PASCA } \\
\text { KUALIFIKASI }\end{array}$ \\
\hline $\begin{array}{l}\text { 1. Pelelangan } \\
\text { umum pekerja } \\
\text { yang bersifat }\end{array}$ & $\begin{array}{l}\text { 1. Pelelangan } \\
\text { umum. } \\
\text { 2. Pelelangan }\end{array}$ \\
\hline $\begin{array}{l}\text { 2. Pelelangan } \\
\text { terbatas. }\end{array}$ & $\begin{array}{l}\text { 3. Pemilihan } \\
\text { langsung. }\end{array}$ \\
\hline $\begin{array}{l}\text { 3. Penunjukan } \\
\text { langsung } \\
\text { bukan untuk } \\
\text { menangani } \\
\text { keadaan } \\
\text { darurat. }\end{array}$ & $\begin{array}{l}\text { 4. Penunjukan } \\
\text { langsung } \\
\text { untuk } \\
\text { mengatasi } \\
\text { keadaan } \\
\text { darurat. }\end{array}$ \\
\hline $\begin{array}{l}\text { 4. Pengadaan } \\
\text { penyedia jasa } \\
\text { konsultansi } \\
\text { badan usaha. }\end{array}$ & $\begin{array}{l}\text { 5. Pemilihan } \\
\text { penyedia jasa } \\
\text { konsultan } \\
\text { perseorangan. }\end{array}$ \\
\hline
\end{tabular}

\section{PENUTUP}

\section{Kesimpulan}

Mekanisme pelaksanaan Pengadaan Barang/Jasa yaitu melalui swakelola dan/atau pemilihan penyedia barang/jasa. Swakelola adalah pekerjaan yang direncanakan, dikerjakan dan diawasi sendiri oleh institusi, dimana dalam pelaksanaannya dapat dilaksanakan oleh PPK, instansi pemerintah lain atau kelompok masyarakat/LSM penerima hibah.sedangkan untuk pemilihan penyedia barang/jasa dapat melalui : pelelangan umum, pelelangan sederhana, penunjukan langsung, kontes/sayembara, pemilihan langsung, pelelangan terbatas, pengadaan langsung. Prinsip-prinsip dalam pengadaan barang/jasa pemerintah, meliputi prinsip efisien, prinsip efektif, prinsip transparan, prinsip terbuka, prinsip bersaing, prinsip adil/tidak diskriminatif dan prinsip akuntabel.

Sedangkan etika yang harus dipatuhi antara lain melaksanakan tugas secara tertib, penuh rasa tanggungjawab, demi kelancaran dan ketepatan tercapainya tujuan pengadaan barang/jasa, bekerja secara professional dengan menjunjung tinggi kejujuran, kemandirian, dan menjaga informasi yang bersifat rahasia, tidak saling mempengaruhi secara langsung maupun tidak langsung yang mengakibatkan persaingan tidak sehat, penurunan kualitas proses pengadaan.

\section{Saran}

Peraturan Presiden Nomer 4 Tahun 2015 di satu sisi membawa kemajuan yang pesat dengan mempercepat proses pelaksanaan pengadaan (pengumuman RUP dan pemilihan penyedia lebih awal), optimalisasi penggunaan e-procurement dan e-purchasing. Di sisi lain harus disadari bahwa ada bahaya yang cukup besar jika tidak dikelola dengan baik.

\section{DAFTAR PUSTAKA}

Peraturan Presiden Republik Indonesia Nomor 54 Tahun 2010 Tentang Pengadaan Barang/Jasa Pemerintah

Peraturan Presiden Republik Indonesia Nomor 35 Tahun 2011 Tentang Pengadaan Barang/Jasa Pemerintah

Peraturan Presiden Republik Indonesia Nomor 70 Tahun 2012 Tentang Pengadaan Barang/Jasa

Pemerintah Peraturan Presiden Republik Indonesia Nomor 172 Tahun 2014 Tentang Pengadaan Barang/Jasa Pemerintah

Peraturan Presiden Republik Indonesia Nomor 4 Tahun 2015 Tentang Pengadaan Barang/Jasa Pemerintah

Shopian, Abu. Dasar-Dasar Pengadaan barang/Jasa pemerintah. Palambang: IN MEDIA, 2014. 
